\title{
AKTIVITAS ANTIBAKTERI EKSTRAK DAN FRAKSI DARI EKSTRAK METANOL DAUN MANGGIS (Garcinia mangostana) PADA BAKTERI PENYEBAB ULKUS DIABETIK
}

\author{
Antibacterial Activities Of Extract And Fraction From Methanol Extract From \\ Manggis Leaves (Garcinia mangostana) In Bacteria Causing Diabetic Ulcer
}

\author{
Vivi Rosalina ${ }^{\text {** }}$ \\ R. Mahendra ${ }^{2}$ \\ *I STIKES Bhakti Husada Mulia, \\ Madiun, Jawa Timur, Indonesia \\ 2 STIKES Bhakti Husada Mulia, \\ Madiun, Jawa Timur, Indonesia \\ *email: \\ newerikania87@gmail.com
}

\begin{abstract}
Abstrak
Diabetes mellitus (DM) adalah penyakit degeneratif karena gangguan metabolisme dengan kondisi hiperglikemik akut sampai kronis. Komplikasi penyakit ini adalah neuropati perifer yang diperparah dengan infeksi bakteri menyebabkan ulkus (luka) pada kaki, tangan, lutut, punggung dan bagian tubuh yang lain. Tanaman manggis (Garcinia mangostana) dipercaya secara empiris memiliki khasiat sebagai antidiabetes dan menyembuhkan ulkus diabetik. Penelitian ini bertujuan untuk mengetahui perbandingan aktivitas antibakteri ekstrak dan fraksi dari ekstrak metanol daun manggis pada konsentrasi $20 \%, 40 \%, 60 \%, 80 \%$ dan $100 \%$ terhadap bakteri penyebab ulkus diabetik secara in vitro. Tahapan penelitian diawali dengan ekstraksi serbuk daun manggis secara maserasi menggunakan pelarut metanol. Fraksi diperoleh dengan metode Kromatografi cair vakum $(\mathrm{KCV})$. Bakteri penyebab ulkus diabetik diperoleh dari specimen ulkus penderita ulkus diabetik. Aktivitas antibakteri ekstrak dan fraksi pada 5 seri konsentrasi diuji menggunakan metode difusi cakram dengan kontrol negatif DMSO $10 \%$ dan kontrol positif yaitu Amoxicillin, Ampicillin, Ciprofloxacin, Cefotaxim, Gentamycin, Erythromicin dan Doxycicline. Aktivitas antibakteri dinyatakan dengan besarnya luas zona hambat pada media yang telah diinokulasikan dengan bakteri ulkus dan diinkubasi selama 24 jam pada suhu $370 \mathrm{C}$. Hasil penelitian diperoleh bahwa terdapat 5 bakteri dominan ditemukan dalam specimen ulkus diabetik yaitu Escherichia spp, klebsiella spp, staphylococcus spp, salmonella spp dan shigella spp. Hasil uji sensitivitas 7 antibakteri diperoleh bahwa ciprofloxacin memiliki luas zona hambat terbesar dibandingkan Amoxicillin, Ampicillin, Cefotaxim, Gentamycin, Erythromicin dan Doxycicline sehingga Ciprofloxacin dapat digunakan sebagai kontrol positif. Hasil uji aktivitas antibakteri ekstrak metanol daun manggis konsentrasi $100 \%$ menghasilkan zona hambat paling besar yaitu 27,10 mm $\pm 0,1$ dibandingkan ekstrak metanol, fraksi $A, B$ dan $C$ pada semua seri konsentrasi. Akan tetapi zona hambat ekstrak metanol daun manggis konsentrasi $100 \%$ tersebut lebih kecil dibandingkan dengan kontrol positif ciprofloxacin $5 \mu \mathrm{g} /$ disk yaitu sebesar $35,01 \mathrm{~mm} \pm 0, \mathrm{I}$
\end{abstract}

\section{Abstract}

Diabetes mellitus (DM) is a degenerative disease due to metabolic disorders with acute to chronic hyperglycemic conditions. The complication of this disease is peripheral neuropathy exacerbated by bacterial infection causing ulcers (sores) on the feet, han ds, knees, back and other parts of the body. The mangosteen plant (Garcinia mangostana) is empirically believed to have antidiabetic and cure diabetic ulcers. This study aims to determine the comparison of the antibacterial activity of extracts and fractions of methanol extract of mangosteen leaves at concentrations of $20 \%, 40 \%, 60 \%, 80 \%$ and $100 \%$ against the bacteria causing diabetic ulcers by in vitro. The research began with maceration of mangosteen leaf powder extraction using methanol as a solvent. The fractions were obtained by the vacuum liquid chromatography (KCV) method. The bacteria that cause diabetic ulcers are obtained from ulcer specimens of diabetic ulcer patients. Antibacterial activity of extracts and fractions at 5 concentration series was tested using the disc diffusion method with 10\% DMSO negative control and positive controls namely Amoxicillin, Ampicillin, Ciprofloxacin, Cefotaxim, Gentamycin, Erythromicin and Doxycicline. Antibacterial activity was expressed by the large area of the inhibition zone on the media that had been inoculated with ulcer bacteria and incubated for 24 hours at $370 \mathrm{C}$. The results showed that there were 5 dominant bacteria found in the diabetic ulcer specimens, namely Escherichia spp, Klebsiella spp, Staphylococcus spp, salmonella spp and shigella spp. The results of the antibacterial sensitivity test showed that ciprofloxacin had the largest area of inhibition zone compared to Amoxicillin, Ampicillin, Cefotaxim, Gentamycin, Erythromicin and Doxycicline so that Ciprofloxacin could be used as a positive control. The results of the antibacterial activity test for the methanol extract of mangosteen leaves with a concentration of $100 \%$ produced the largest inhibition zone, namely $27.10 \mathrm{~mm} \pm 0.1$ compared to methanol extract, fractions $A, B$ and $C$ in all concentration series. However, the inhibition zone of the $100 \%$ concentration of mangosteen leaves methanol extract was smaller than the positive control of ciprofloxacin $5 \mu \mathrm{g} /$ disk, which was $35.01 \mathrm{~mm} \pm 0.1$

(C) year The Authors. Published by Institute for Research and Community Services Universitas Muhammadiyah Palangkaraya. This is Open Access article under the CC-BY-SA License (http://creativecommons.org/licenses/by-sa/4.0/). DOI: https://doi.org//0.33084/jsm.vxix.xxx. 


\section{PENDAHULUAN}

Diabetes mellitus (DM) merupakan salah satu penyakit degeneratif yang disebabkan metabolisme kompleks ditandai dengan kondisi hiperglikemik yang kronis (Kernel dan Bruckel, 20I4). Kondisi ini menyebabkan meningkatkan risiko komplikasi seperti neuropati perifer yang diperparah dengan infeksi bakteri menyebabkan ulkus pada kaki, tangan, lutut, punggung dan bagian tubuh yang lain (Supiyanti, 2010). Prevalensi penyakit DM di Indonesia terus tumbuh dan meningkat berdasarkan pemeriksaan darah adalah 10,9\% dan diagnosis dokter sebesar I,5\% (Riskesdas, 2018). Angka kematian pada penderita DM dengan ulkus berkisar antara 17-23\% dan diamputasi berkisar antara 15-30\% (Syarif, 20I3). Penderita ulkus diabetik di Indonesia memerlukan biaya yang tinggi sebesar I,3 juta sampai Rpl,6 juta perbulan dan Rp 43,5 juta per tahun untuk seorang penderita (Hastuti, 20l0).

Keberadaan bakteri menjadi penyebab awal adanya luka (ulkus) yang terjadi saat kondisi hiperglikemik membuat bakteri tumbuh dan berkembang. Bakteri yang terdapat di dalam ulkus diabetik adalah kumpulan bakteri aerob dan anaerob (Nur dan Malisa, 2016). Anggriawan (2014) melaporkan bahwa bakteri aerob dan anaerob terdapat dalam kultur specimen (pus) penderita ulkus diabetik, yaitu Enterobacter sp. (48\%), Staphylococcus aureus (18,2\%), Streptococcus spp (16.8\%), dan Pseudomonas sp (I7 \%). Tahir dan Nurwahidah (2019) juga melaporkan bahwa bakteri gram negatif golongan Proteus mirabilis memiliki nilai tertinggi pertama yang menginfeksi ulkus diabetik sebesar 20,5\% dan kedua adalah E. coli sebesar 17,6 \%. Perbedaan jenis bakteri pada ulkus diabetik dipengaruhi oleh trauma, kelainan biomekanik, keterbatasan gerak sendi, dan peningkatan resiko infeksi. Pengobatan ulkus diabetik adalah dengan antibiotik (Lipsky BA et al, 2012). Akan tetapi, pengobatan dengan antibiotik perlu dikaji ulang karena terdapat bakteri yang resisten terhadap antibiotik tertentu.
Penggunaan bahan alami sebagai alternatif pengobatan ulkus diabetik telah banyak diteliti diantaranya perawatan dan penyembuhan ulkus diabetik menggunakan serat pelepah pisang kombinasi dengan rumput laut oleh Juwono dan Sudiarto (2017), ekstrak cacing oleh Mardianti dkk (20II) dan ekstrak kunyit oleh Doddy dkk (2017). Penelitian sebelumnya tentang tanaman manggis (Garcinia mangostana) diantaranya yaitu ekstrak kulit manggis mampu menurunkan kadar gula tikus yang diinduksi alloksan pada dosis sebesar $500 \mathrm{mg} / \mathrm{kg}$ BB (Dyahnugra dan Widjanarko, 2015), Pasaribu dkk (2012) melaporkan ekstrak etanol kulit buah manggis mampu menurunkan kadar gula darah mencit pada dosisi $100 \mathrm{mg} / \mathrm{kg}$ BB. Penelitian tentang perbandingan aktivitas antibakteri ekstrak dan fraksi dari ekstrak metanol daun manggis terhadap bakteri penyebab ulkus diabetik belum pernah dilakukan, sehingga penelitian ini sangat diperlukan untuk menemukan solusi alternatif pengobatan atau perawatan ulkus diabetik.

\section{METODOLOGI}

Metode yang dilakukan meliputi pembuatan ekstrak daun Manggis sebanyak $2 \mathrm{~kg}$ Serbuk Daun manggis dimaserasi menggunakan pelarut metanol sebanyak 20 liter. Selanjutnya maserat dipekatkan dengan rotaryevaporator. Selanjutnya fraksinasi diakukan secara ecc dimana ekstrak kental dipartisi menggunakan $100 \mathrm{ml}$ pelarut $\mathrm{n}$ heksan sebanyak 4 kali menghasilkan fraksi metanol dan fraksi $\mathrm{n}$ heksan. Selanjutnya fraksi metanol dipartisi menggunakan 100 $\mathrm{ml}$ pelarut etil asetat sebanyak 3 kali. Fraksi etil asetat yang dihasilkan dipekatkan menggunakan rotaryevaporator. Fraksi etil asetat yang telah dimpregnasi menggunakan silika gel difraksinasi menggunakan fase diam silika gel dan fase gerak nheksan, etil asetat dan $\mathrm{n}$ butanol. Proses elusi dilakukan dengan pelarut mulai dari kepolaran rendah yaitu n-heksana lalu kepolaran ditingkatkan dari $n$ heksan, etil asetat sampai $\mathrm{n}$ butanol. Kolom dihisap 
sampai kering pada setiap pengumpulan fraksi. Tiap fraksi dipekatkan dengan rotaryevaporator.

Ekstrak dan fraksi diidentifikasi fitokimia meliputi Uji steroid/triterpen dengan menambah sampel ekstrak kental dengan asam asetat anhidrida dan asam sulfat pekat (pereaksi Liebermann Burchard) menghasilkan warna biru atau biru hijau menunjukkan adanya steroid, sedangkan warna merah, merah muda atau ungu menunjukkan adanya triterpenoid. Uji flavonoid dengan menambah sampel yang telah digerus dalam mortir dengan sedikit air, pindahkan dalam tabung reaksi, ditambahkan sedikit logam magnesium dan 5 tetes $\mathrm{HCl} 2 \mathrm{~N}$, seluruh campuran dipanaskan selama 5-10 menit. Setelah disaring panas- panas dan filtrat dibiarkan dingin, filtrat ditambahkan amil alkohol, lalu dikocok kuat-kuat. Reaksi positif dengan terbentuknya warna merah pada lapisan amil alkohol (Depkes RI, 1989). Uji alkaloid dilakukan dengan sampel dalam mortir, dibasakan dengan amonia sebanyak I $\mathrm{mL}$, kemudian ditambahkan kloroform dan digerus kuat. Cairan kloroform disaring, filtrat ditempatkan dalam tabung reaksi kemudian ditambahkan $\mathrm{HCl} 2 \mathrm{~N}$, campuran dikocok, lalu dibiarkan hingga terjadi pemisahan. Dalam tabung reaksi terpisah dilakukan reaksi yang dapat menunjukkan adanya alkaloid yaitu filtrat ditambahkan I tetes larutan pereaksi Dragendorff menunjukkan adanya endapan atau kekeruhan berwarna hingga coklat, dan sisa filtrat ditambahkan I tetes larutan pereaksi Mayer menunjukkan endapan atau kekeruhan berwarna putih. Uji saponin dilakukan dengan ekstrak kental sebanyak I g ditambahkan dengan air hangat, dikocok vertikal selama 10 detik kemudian dibiarkan selama 10 detik. Pembentukan busa setinggi $\mathrm{I}-10 \mathrm{~cm}$ yang stabil selama tidak kurang dari 10 menit, menunjukkan adanya saponin. Pada penambahan I tetes $\mathrm{HCl} 2 \mathrm{~N}$, busa tidak hilang (Depkes RI, 1995). Uji Tannin dilakukan dengan Sebanyak $200 \mathrm{mg}$ ekstrak dilarutkan dengan $20 \mathrm{ml}$ air panas lalu dikocok hingga homogen. setelah dingin ditambah $\mathrm{FeCl}_{3} 3 \%$ menunjukkan hasil positif jika terbentuk larutan biru kehitaman atau hijau kecoklatan.

Specimen ulkus diabetik diambil dengan metode swabbing dengan cotton swab steril sebanyak 3 kali swabbing kemudian dibawa ke Laboratorium Mikrobiologi STIKES Bhakti Husada Mulia Madiun menggunakan box sampel dalam keadaan dingin. Specimen didilusi pada effendor dengan pengenceran mulai dari 101 sampai $107 \mathrm{CFU} / \mathrm{uL}$. Proses sterilisasi alat dan media uji menggunakan autiklaf pada suhu I 2 I OC selama 15 menit. Media-media yang digunakan adalah media NA yang dibuat dengan cara $20 \mathrm{~g}$ Nutrient Agar (NA) dilarutkan dalam I liter akuades, dipanaskan hingga mendidih sampai larut, media Mac conkay cair $20 \mathrm{ml}$ dituangkan kedalam cawan petri dan biarkan memadat. Media Tsi dibuat dengan I,5 ditambah aquadest $50 \mathrm{ml}$, dipanaskan hingga mendidih sampai larut, media SIM dibuat dengan 2 gram media ditambahkan aquades $50 \mathrm{ml}$, dipanaskan hingga mendidih, media Simmon sitrat agar (citrate) dibuat dengan I,5 gram ditambah aquadest $50 \mathrm{ml}$. Semua media disterilkan menggunakan autoklaf pada suhu I2IoC selama 15 menit, kemudian dituangkan ke dalam cawan petri dan dibiarkan hingga memadat.

Identifikasi Bakteri Pada Specimen Ulkus Diabetik dilakukan berdasarkan bakteri yang tumbuh pada media Nutrient Agar (NA) dan Mac conkay yang selanjutnya dilakukan pewarnaan gram. Identifikasi bakteri dilanjutkan dengan uji biokimia dengan inokulasi bakteri media TSI (Tripple Sugar Iron), SIM (Sulfida Indole Motility), citrate, MR-VP dan LIA (Lactosa Iron Agar), diinkubasi selama 24 jam pada suhu 370 C. Selanjutnya dilakukan uji sensitivitas antibiotik untuk menentukan antibiotik yang memiliki sensitivitas tinggi dalam menghambat pertumbuhan bakteri hasil isolasi ulkus diabetik. Antibiotik yang digunakan dalam uji sensitivitas yaitu Amoxicillin (10 ug), Ampicillin (10 ug), Ciprofloxacin (5 ug), Cefotaxim (30 ug), Gentamycin (10 ug), Erythromicin (15 ug) dan Doxycicline (30 ug) per disk nya. Aktivitas Antibakteri 
Jurnal Surya Medika (JSM), Vol x No x, Month Year, Page $x-x$ p-ISSN: 2460-7266; e-ISSN: 2655-205I 4 Ekstrak dan Fraksi dari Ekstrak Metanol Daun Manggis menggunakan metode difusi cakram secara in vitro dengan kontrol negatif pelarut dimethyl sulfoxide $10 \%$ (DMSO) dan sampel yang di uji yaitu ekstrak dan fraksi dari ekstrak metanol daun manggis pada masing-masing konsentrasi sebesar 20\%, 40\%, 60\%, $80 \%$ dan $100 \%$.

\section{HASIL DAN PEMBAHASAN}

Daun manggis (Garcinia mangostana) diperoleh dari perkebunan manggis di desa Dagangan Kabupaten Madiun. Daun manggis yang diperoleh sebessar $20 \mathrm{~kg}$ daun basah. Daun manggis segar yang diperoleh menghasilkan daun manggis kering sebesar 9,3 kg. Simplisia kering daun diserbuk menggunakan blender sampai diperoleh serbuk yang halus. Serbuk yang diperoleh sebesar 4,86 kg. Ekstraksi secara maserasi menggunakan pelarut metanol menghasilkan ekstrak metanol sebesar 287,2 gram dengan rendemen $14,6 \%$. Banyaknya rendemen bergantung kepada sifat kelarutan komponen bioaktifnya. Hal ini dikarenakan kelarutan zat pada suatu pelarut sangat ditentukan oleh kemampuan zat tersebut membentuk ikatan hidrogen (Khopkar, 1990). Beberapa faktor yang dapat mempengaruhi hasil rendemen adalah waktu ekstraksi, metode ekstraksi yang digunakan, ukuran sampel, penyimpanan, dan perbandingan jumlah sampel dengan jumlah pelarut. Nilai rendemen dapat diartikan dengan banyaknya kandungan senyawa aktif. Tingginya senyawa bioaktif yang terdapat pada suatu ekstrak ditunjukkan dengan besarnya rendemen ekstrak.

Pelarut yang digunakan untuk maserasi adalah metanol. Menurut ismail et al (2004) dalam Ningsih (2017) metanol dipilih sebagai pelarut karena memiliki kepolaran yang tinggi sehingga mampu melarutkan sebagian besar senyawa yang ada dalam simplisia dapat terekstrak di dalam metanol. Pelarut dengan kepolaran rendah, lebih sedikit menarik ekstrak aktif dibandingkan dengan campuran etanol dan metanol atau metanol saja. Fraksinasi ekstrak metanol daun manggis secara ECC menghasilkan fraksi etil asetat. Fraksi etil asetat difraksinasi secara KCV menggunakan pelarut $\mathrm{n}$ heksan, etil asetat dan $\mathrm{n}$ butanol menghasilkan kelompok fraksi yang dikelompokkan berdasarkan profil kromatografi lempeng tipis (KLT). Monitoring secara KLT menggunakan fase diam silika gel 60 F254 dan fase gerak etil asetat : asam format : air (8:0,5:0,5), dipertegas dengan uap ammonia, dilihat dibawah sinar UV $254 \mathrm{~nm}$ dan $366 \mathrm{~nm}$.

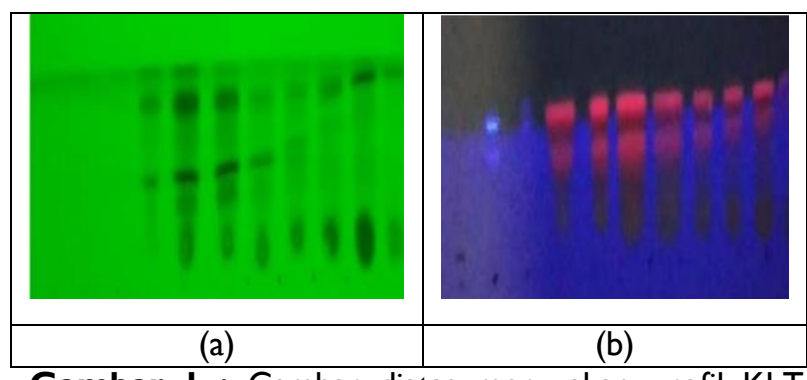

Gambar I : Gambar diatas merupakan profil KLT fraksi hasil KCV yang diamati dibawah sinar UV 254 dan 366. (a)

Profil KLT UV 254, (b) Profil KLT UV 366 Pada profil KLT diatas tampak bercak yang tampak menunjukkan adanya senyawa metabolit sekunder dalam fraksi hasil KCV. Bercak-bercak tersebut selanjutnya di hitung nilai Rf nya dan kelompokkan berdasarkan profilnya. Berikut adalah data berat fraksi hasil KCV dan pengelompokan berdasarkan nilai Rf.

Tabel I. Data Pengelompokkan Fraksi

\begin{tabular}{|c|c|c|c|}
\hline Fraksi & Nilai Rf I & Nilai Rf 2 & Kelompok \\
\hline I & 0 & 0 & \multirow{3}{*}{ A } \\
\hline 2 & 0 & 0 & \\
\hline 3 & 0 & 0 & \\
\hline 4 & 0,36 & 0,68 & \multirow{3}{*}{ B } \\
\hline 5 & 0,36 & 0,64 & \\
\hline 6 & $0,4 I$ & 0,65 & \\
\hline 7 & 0,41 & 0,64 & \multirow{5}{*}{ C } \\
\hline 8 & 0,41 & 0,64 & \\
\hline 9 & 0,41 & 0,65 & \\
\hline 10 & 0,41 & 0,65 & \\
\hline 11 & 0,42 & 0,65 & \\
\hline
\end{tabular}

Hasil Identifikasi fitokimia diperoleh Berdasarkan tabel diatas, ekstrak metanol mengandung senyawa metabolit sekunder yaitu alkaloid, flavonoid, tannin, saponin dan polifenol. Fraksi etil asetat mengandung 
alkaloid, flavonoid dan polifenol. Sedangkan fraksi $\mathrm{N}$ heksan mengandung steroid. Hasil identifikasi fitokimia dapat dilihat pada table dibawah ini :

Tabel 2. Hasil Identifikasi Fitokimia

\begin{tabular}{|c|c|c|c|c|}
\hline Senyawa & Metode & EM & FEA & FNH \\
\hline Alkaloid & Dragendroff & + & + & - \\
\hline Flavonoid & $\begin{array}{l}\text { Serbuk } \mathrm{Mg}, \\
\mathrm{HCl} \text { pekat }\end{array}$ & + & + & - \\
\hline Tanin & $\mathrm{FeCl}_{3}$ & + & - & - \\
\hline Saponin & $\begin{array}{l}\text { Pembentukan } \\
\text { Busa }\end{array}$ & + & - & - \\
\hline Polifenol & $\mathrm{FeCl}_{35 \%}$ & + & + & - \\
\hline Steroid/Terpenoid & $\begin{array}{l}\text { Lieberman } \\
\text { Burchard }\end{array}$ & - & - & + \\
\hline
\end{tabular}

Keterangan : EM= Ekstrak methanol, FEA=Fraksi etil asetat, $\mathrm{FNH}=$ Graksi $\mathrm{N}$ heksan

Hasil Identifikasi Bakteri Ulkus Diabetik Identifikasi bakteri dalam specimen ulkus diabetik dilakukan dengan isolasi dimana specimen ulkus yang telah diencerkan sebanyak 7 kali dengan $\mathrm{NaCl}$, kemudian diinokulasikan pada media Nutrient agar dan Mac conkay. Selanjutnya dilakukan pewarnaan gram menghasilkan bakteri dengan morfologi sebagai berikut.

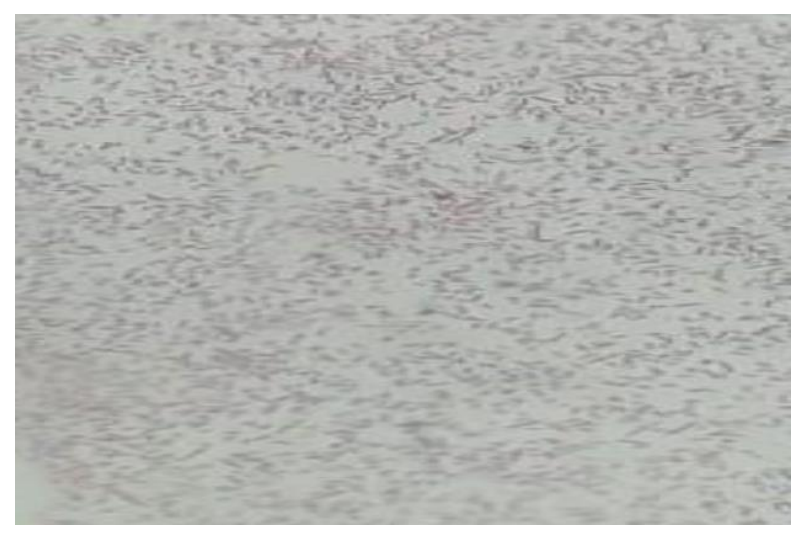

Gambar 2. Foto Bakteri hasil pewarnaan gram berbentu batang dan berwarna merah

Berdasarkan hasil pewarnaan gram diatas dapat diketahui bahwa bakteri yang terdapat pada specimen ulkus diabetik memiliki bentuk batang dan berwarna merah muda. Hidayat (20I I) menyebutkan sel bakteri gram positif yang ditambah pewarna kristal violet akan berwarna ungu karena menyerap pewarna tersebut. Ketika ditamba dengan lugol dan dicuci dengan alcohol akan tetap berwarna ungu karena sel bakteri kuat mengikat kompleks Kristal violet-lugol. Sedangkan bakteri Gram negatif akan menjadi tidak berwarna ketika ditambah kristal violet karena bakteri gram negatif memiliki lapisan peptidoglikan yang tipis, ketika ditambah dengan safranin maka akan diserap dan sel bakteri gram negatif berwarna merah. Hasil identifikasi bakteri secara biokimia sebagai berikut :

Tabel 3. Hasil Uji Biokimia

\begin{tabular}{|c|c|c|c|c|c|c|}
\hline \multirow{2}{*}{ No } & \multirow{2}{*}{ Jenis Uji } & \multicolumn{5}{|c|}{ Isolat } \\
\cline { 2 - 7 } & Motilitas & + & + & - & + & - \\
\hline 2 & Indol & - & - & - & + & + \\
\hline 3 & MR & - & - & - & - & + \\
\hline 4 & VP & + & + & + & - & + \\
\hline 5 & TSIA & - & - & + & & \\
\hline & Sukrosa & - & - & + & + & + \\
\hline & Laktosa & + & - & + & - & + \\
\hline & Glukosa & + & - & + & + & + \\
\hline & Gas & + & - & + & + & + \\
\hline & H.S & - & - & - & + & + \\
\hline 6 & Simmon Citrat & - & + & + & + & + \\
\hline 7 & LIA & + & - & + & + & - \\
\hline
\end{tabular}

Berdasarkan Uji biokimia diperoleh 5 bakteri dominan yang terdapat pada specimen ulkus diabetik yaitu isolat I adalah Enterobacter spp, isolat II Shigella spp, isolat III Klebsiella spp, isolat IV Pseudomonas spp dan isolat V Salmonella spp. Sebelum dilakukan uji aktivitas antibakteri telah dilakukan uji sensitivitas antibiotik terhadap bakteri penyebab ulkus diabetik. Hasil uji sensitivitas aantibiotik terhadap bakteri penyebab ulkus diabetik adalah sebagai berikut :

Tabel 4. Hasil Uji Sensitivitas Antibiotik

\begin{tabular}{|c|l|c|}
\hline No & Antibiotik & $\begin{array}{l}\text { Rata-rata Zona } \\
\text { Hambat } \mathbf{( m m})\end{array}$ \\
\hline I & Amoxicillin I0 ug & $7,03 \pm 0,06$ \\
\hline 2 & Ampicillin 10 ug & $0 \pm 0$ \\
\hline 3 & Ciprofloxacin 5 ug & $35,1 \pm 0,1$ \\
\hline 4 & Cefotaxim 30 ug & $25,03 \pm 0,05$ \\
\hline 5 & Gentamycin I0 ug & $15,0 \pm 0$ \\
\hline 6 & Eryithromycin I5 ug & $6,07 \pm 0,06$ \\
\hline 7 & Doxycicline 30 ug & $20,63 \pm 0,64$ \\
\hline
\end{tabular}

Berdasarkan hasil uji sensitivitas kelompok antibiotik yang paling sensitif terhadap bakteri penyebab ulkus 
diabetik yaitu Ciprofloxacin 5 ug/disk dan mammpu menghambat pertumbuhan antibakteri terbesar dibandingkan yang lain. Hasil Uji antibakteri terhadap bakteri penyebab ulkus diabetik adalah sebagai berikut

Tabel 4. Hasil Uji Aktivitas Antibakteri

\begin{tabular}{|c|c|c|}
\hline No & Kelompok Uji & $\begin{array}{l}\text { Rata-rata Zona } \\
\text { Hambat (mm) }\end{array}$ \\
\hline I & K (-) DMSO I0\% & 0 \\
\hline 2 & 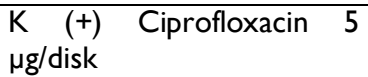 & $35,10 \pm 0,1$ \\
\hline 3 & Ekstrak Metanol 20\% & $5,0 \pm 0$ \\
\hline 4 & Ekstrak Metanol 40\% & $10,13 \pm 0,11$ \\
\hline 5 & Ekstrak Metanol $60 \%$ & $15,07 \pm 0, I \mid$ \\
\hline 6 & Ekstrak Metanol $80 \%$ & $20,07 \pm 0,06$ \\
\hline 7 & Ekstrak Metanol 100\% & $27,0 \mathrm{I} \pm 0, \mathrm{I}$ \\
\hline 8 & Fraksi A 20\% & $0 \pm 0$ \\
\hline 9 & Fraksi A 40\% & $0 \pm 0$ \\
\hline 10 & Fraksi A 60\% & $0 \pm 0$ \\
\hline II & Fraksi A 80\% & $0 \pm 0$ \\
\hline 12 & Fraksi A 100\% & $2, I \pm 0, I$ \\
\hline 13 & Fraksi B 20\% & $5,03 \pm 0,06$ \\
\hline 14 & Fraksi B 40\% & $7,07 \pm 0, I I$ \\
\hline 15 & Fraksi B 60\% & $1 \mathrm{I}, 10 \pm 0,10$ \\
\hline 16 & Fraksi B 80\% & $13,03 \pm 0,06$ \\
\hline 17 & Fraksi B 100\% & $15,13 \pm 0,15$ \\
\hline 18 & Fraksi C 20\% & $0 \pm 0$ \\
\hline 19 & Fraksi C 40\% & $0 \pm 0$ \\
\hline 20 & Fraksi C 60\% & $0 \pm 0$ \\
\hline 21 & Fraksi C 80\% & $2,9 \pm 0,1$ \\
\hline 22 & Fraksi C I00\% & $3,93 \pm 0,06$ \\
\hline
\end{tabular}

Berdasarkan hasil uji aktivitas antibakteri diatas diperoleh bahwa ekstrak metanol daun manggis memiliki potensi menghambat pertumbuhan bakteri penyebab ulkus diabetik pada konsentrasi $20 \%$ sebesar $5,0 \mathrm{~mm} \pm 0,40 \%$ sebesar 10,13 mm $\pm 0,11$, $60 \%$ sebesar I5,07 $\mathrm{mm} \pm 0,1 \mathrm{I}, 80 \%$ sebesar 20,07 $\mathrm{mm} \pm$ 0,06 dan $100 \%$ sebesar 27,0I $\mathrm{mm} \pm 0, \mathrm{I}$. Pada konsentrasi $100 \%$ ekstrak metanol daun manggis mampu menghambat pertumbuhan bakteri penyebab ulkus diabetik dengan luas zona hambat terbesar yaitu sebesar $27,0 \mathrm{I} \mathrm{mm} \pm 0, \mathrm{I}$.

Fraksi ekstrak metanol daun manggis (Garcinia mangostana) hasil KCV juga memiliki potensi sebagai antibakteri pada konsentrasi tertentu. Berdasarkan hasil fraksinasi secara kromatografi cair vakum diperoleh II fraksi yang dikelompokkan menjadi 3 fraksi besar yaitu fraksi A, B dan C. Ketiga kelompok besar fraksi diuji aktivitas antibakterinya pada konsentrasi $20 \%, 40 \%, 60 \%, 80 \%$ dan $100 \%$. Pada ketiga kelompok besar fraksi diperoleh fraksi B pada konsentrasi $100 \%$ mampu menghambat pertumbuhan bakteri penyebab ulkus diabetik terbesar yaitu sebesar 15, I $3 \mathrm{~mm} \pm 0,15$ dibandingan dengan fraksi $A$, fraksi $B$ dan fraksi $C$ pada semua seri konsentrasi. Sehingga dapat disimpulkan bahwa ekstrak metanol memiliki aktivitas antibakteri yang paling baik dibanding ketiga fraksi lainnya.

Berdasarkan hasil pengujian ktivitas antibakteri dari ekstrak metanol, fraksi $A$, fraksi $B$, dan fraksi $C$ dapat diketahui bahwa aktivitas antibakteri yang paling baik dihasilkan oleh konsentrasi $100 \%$. Hal ini dikarenakan semakin tinggi konsentrasi suatu bahan antimikroba maka aktivitas antimikroba nya semakin besar pula (Ningsih dkk, 20l7). Mekanisme kerja antibakteri dari senyawa metabolit sekunder yaitu alkaloid bekerja dengan mengganggu integritas komponen penyusun peptidoglikan pada sel bakteri(Rahman dkk, 2016). Flavonoid dapat menghambat sintesis asam nukleat, menghambat fungsi membran sel dan menghambat metabolisme energi (Rahman dkk, 2016). Saponin meningkatkan permeabilitas membrane sel sehingga membran menjadi tidak stabil dan mengakibatkan hemolisis sel. Tanin bekerja dengan menonaktifkan adhesin bakteri, menghambat kerja enzim, menghambat transport protein pada selubung sel. (Rahman dkk, 20l6). Polifenol mendenaturasi dan koagulasi protein menyebabkan presipitasi serta denaturasi protein menyebabkan koagulasi protein dan 
sel membran mengalami lisis (Wulandari , 2009). Steroid menyebabkan kebocoran pada liposom bakterii dengan berinteraksi dengan membran fosfolipid menyebabkan integritas membran menurun serta morfologi membran sel berubah menyebabkan sel rapuh dan lisis (Thresia, 2016).

\section{KESIMPULAN}

Berdasarkan hasil penelitian dapat disimpulkan bahwa ekstrak metanol daun manggis pada konsentrasi $100 \%$ memiliki aktivitas antibakteri terbesar dengan zona hambat $27,0 \mathrm{I} \mathrm{mm} \pm 0, \mathrm{I}$ dibandingan dengan ekstrak metanol pada konsentrasi $20 \%, 40 \%, 60 \%, 80 \%$, Fraksi A, Fraksi B dan Fraksi C pada semua seri konsentrasi. Saran untuk penelitian selanjutnya adalah isolasi dan identifikasi bakteri dari specimen ulkus diabetik menggunakan Uji biokimia, katalase, dan PCR.

\section{UCAPAN TERIMA KASIH}

Pertama, Peneliti mengucapkan terima kasih kepada Kemenristek (Kementrian Riset dan Teknologi) selaku pemberi dana hibah skema Penelitian Dosen pemula (PDP), sehingga peneliti bisa menyelesaikan. sebagai Berisi Informasi ucapan terima kasih serta penghargaan kepada pihak-pihak yang telah berpartisipasi dalam kegiatan penelitian yang dilakukan. Kedua, Peneliti mengucapkan terimakasih kepada institusi yaitu STIKES Bhakti Husada Mulia Madiun atas dukungannya sehingga peneliti mampu menyelesaikan penelitian ini.

\section{REFERENSI}

I. Kerner, W., Bruckel, J. (20I4). Definition, Classification and Diagnosis of Diabetes Mellitus. Experimental and Clinical Endocrinology Diabetes, I22(7): 384-386

2. Supiyanti W, Wulansari ED, Kusmita L. 2010. Uji Aktvitas Antioksidan Dan Penentuan Kandungan Antosianin Total Kulit Buah Manggis (Garcinia Manggostana L). Majalah Obat Tradisional 15 (2), 64-70
3. Riset Kesehatan Dasar (Riskesdas) (2018). Badan Penelitian dan Pengembangan Kesehatan Kementerian RI tahun 2018.

4. Syarif, H. (20I3). Kualitas hidup pasien ulkus diabetik di poliklinik endokrin RSUDZA, Banda Aceh. Idea Nursing Journal.4(I).

5. Hastuti RT. (Tesis). 2008. Faktor- Faktor Risiko Ulkus Diabetika pada Penderita Diabetes Mellitus (Studi Kasus di RSUD Dr. Moewardi Surakarta). Semarang : Universitas Diponegoro

6. Nur, A., Marissa, N. 2016. Gambaran bakteri ulkus diabetikum di Rumah Sakit Zainal Abidin dan Meuraxa tahun 2015. Buletin Penelitian Kesehatan.44(3): 187-96

7. Anggriawan F. Endriani R. Sembiring LP. 2014. Identifikasi Bakteri Batang Gram Negatif Penghasil Extended Spectrum B Lactamase Dari Ulkus Diabetikum Derajat I Dan II Waigner Di Bangsal Penyakit Dalam RSUD Arifin Achmad Provinsi Riau. Riau : Fakultas Kedokteran Universitas Riau

8. Lipsky BA, Berendt AR, Cornia PB, Pile JC, Peters EJG, Armstrong DG, et al. 2012. Infection Diseases Society of America Clinical Practice Guideline for The Diagnosis and Treatment of Diabetic Foot Infections. Clinical Infectious Diseases. 2012; 54(I2): I32-173

9. Juwono, WP., dan, Sudiarto, Ns. 2017. Inovasi Serat Pelepah Pisang (Musa Paradisiaca) Dengan Jurnal Surya Medika (JSM), Vol x No x, Month Year, Page $x$ - x p-ISSN: 2460-7266; e-ISSN: 2655-205I 8 Rumput Laut (Sargassum Sp) Dalam Perawatan Luka Diabetik Pada Tikus (Rattus Novergicus). Prosiding Seminar Nasional Publikasi Hasil-Hasil Penelitian dan Pengabdian Masyarakat. Universitas Muhammadiyah Semarang

10. Mardiati, NPJ., Yunitasari, AN., Sari, DA., Saraswasta, IWG., Putra, FN., dan Kristianto, H. 20II. Ekstrak Cacing Tanah Sebagai Inovasi Penyembuhan Ulkus Diabetik Berbasis Induksi Densitas Akson. Program Studi Ilmu Keperawatan, Fakultas Kedokteran, Universitas Brawijaya

II. Doddy YP, Muh Mardiyono, Henni Kusuma. 2017. Studi Kasus Uji Pra Klinik Perawatan Ulkus Kaki Diabetic Dengan Topikal Hidrokoloid Kunyit. Jurnal Kebidanan dan Keperawatan, Vol. I3, No. 2

12. Dyahnugra, AA dan Widjanarko, SB. 2015. Pemberian Ekstrak Bubuk Simplisia Kulit Manggis (Garcinia Mangostana L.) Menurunkan Kadar Glukosa Darah Pada Tikus Putih (Rattus 
Norvegicus) Strain Wistar Jantan Kondisi Hiperglikemik. Jurnal Pangan dan Agroindustri. Vol. 3 No I p.II3-123. Jurusan Teknologi Hasil Pertanian, FTP Universitas Brawijaya Malang

13. Pasaribu, F., Sitorus, P dan Bahri, S. 20I2. Uji Ekstrak Etanol Kulit Buah Manggis (Garcinia mangostana L.) Terhadap Penurunan Kadar Glukosa Darah. Journal of Pharmaceutics and Pharmacology, 2012 Vol.I (I): I-8. Universitas Sumatera Utara 